JeAn-Jaques Chanaron ${ }^{\star *}$

Original Scientific Paper

Received 01.10.2017.

Approved 20.10.2017.

\title{
INNOVATION CAPABILITIES OF HI-TECH SMALL AND MEDIUM-SIZED ENTERPRISES (SMES): A Comparative Analysis between China and France
}

The objective of this research is to contribute to academic research by providing new insight into the current hi-tech SMEs' innovation activities. Moreover, the research also concentrates on empirical testing of the questions and the hypotheses which come from the other scholars' visionary ideas like Schumpeter, Freeman, Chanaron etc. This study investigates and compares hi-tech SMEs in China and France showing the differences in innovation capabilities between the two countries. The empirical research is based on a comprehensive questionnaire. Sample firms are randomly selected from Shanghai in China and Rhône-Alpes in France. To control the exogenous industrial variance, sample firms in the two countries with the same proportion of industrial sectors are selected. Relying on quantitative analysis the study concludes that the differences on innovation capabilities are significant. Moreover, the innovation stages of hi-tech firms depend on some key factors, such as R\&D expenditure, firm size, granted patents, profit intensity, new products etc., positively correlated with innovation capabilities. The findings indicate that, compared to their larger counterparts, hi-tech SMEs have distinctive capabilities for innovation which are determined by their resource-constraints and their particular innovation strategy.

Keywords: Innovation, capability, SMEs, performance, France, China

* Institute of Business Administration University of Grenoble Alpes, France, rui.luo@univ-grenoble-alpes.fr, rui.luo@outlook.fr

** Scientific Advisor, Doctoral School, Grenoble Ecole de Management, France, Jean-Jacques.chanaron@wanadoo.fr 


\section{Introduction}

Innovation capability of small and medium enterprises (SMEs) is a crucial issue for all stakeholders, i.e. academic scholars, managers and policy makers. Generally speaking, the literature available is limited and highly controversial. Above all, there are very few peer-reviewed articles comparing SMEs in China with their European counterparts. This paper aims at generating and testing some hypotheses regarding differences or similarities in the two regions.

\section{Key Factors of Innovation Capabilities Evaluation: Lessons from the Literature}

Based on literature, the key factors of innovation capabilities evaluation in SMEs are classified into five areas:

\subsection{From the Perspective of aFirm Size and Age}

Mairesse et al. [1] ${ }^{1}$ show that the propensity to engage in continuous R\&D increases significantly with size. Wang et al. [2] ${ }^{2}$ selected several control variables such as a firm's size, size of the R\&D staff and the amount of R\&D investment. Because a firm's innovation performance may vary with the firm's size, the size of its R\&D staff, and the amount of its R\&D investment, these three variables served as the controls in the study. The size of a firm was estimated by its number of employees. The number of R\&D staff was measured by the number of personnel who were responsible for the firm's product and process innovation work. The amount of $\mathrm{R} \& \mathrm{D}$ investment was estimated using the ratio of the firm's annual $R \& D$ spending to its annual budget in the past five years. The researchers found that both $\mathrm{R} \& \mathrm{D}$ investment and the size of the company contributed positively to an SME's innovation performance, but not the firms' age.

However, several researchers (Leonard-Barton $[3]^{3}$; Sorensen \& Stuart, $[4]^{4}$ ) raised the issue of the firm's age, pointing out that it has a negative effect on

$1 \quad$ Mairesse, J., et al., (2005): The Importance of R\&D and Innovation for Productivity: A Reexamination in Light of the French Innovation Survey, Annals of Economics and Statistics / Annalesd'Économie et de Statistique, No. 79/80, Contributions in memory of ZviGriliches, 487-527.

2 Wang, Y., Ellinger, A. D., (2009): Examining the relationships between information acquisition, entrepreneurial opportunity recognition, and innovation performance through the development and validation of a new measure to assess information acquisition in the high technology sector in Taiwan, International Journal of Entrepreneurship and Innovation Management, 9(3): 313-334.

3 Leonard-Barton, D., (1997): Wellsprings of Knowledge, Boston, MA, Harvard Business School Press.

4 Sorensen, J.B., Stuart, T.E., (2000): Aging, Obsolescence, and Organizational Innovation, Administrative Science Quarterly, 45: 81-112. 
the ability to learn new competencies and thus to innovate. Natarajan et al. [5] $]^{5}$ reveal that the firm'sage is negatively related to innovation and this effect is greater in technological areas. However, Sorensen \& Stuart $[4]^{6}$ find that firm's age is negatively related to innovation capabilities in semiconductors but positively in biotechnology.

Mlouka et al. $[6]^{7}$ conclude that the firm size plays a vital role in the competitive performance, and the medium sized businesses can enjoy the advantages of small firms (such as flexibility, easier social relationship, etc.) and the efficiency of large companies.

Cohen \&Klepper [7] ${ }^{8}$ and Kim et al. [8] ${ }^{9}$ conduct some empirical studies on the relationship between innovative output and firm size, which defines $R \& D$ productivity as patent to $R \& D$ expenditure.

Becker et al. [9] ${ }^{10}$ present that the likelihood of investing in $\mathrm{R} \& \mathrm{D}$ is much lower for small and middle-sized firms than for big firms. The coefficients for size related to the level of $\mathrm{R} \& \mathrm{D}$ expenditures are positive, and in most cases significant. In general, large firms have a higher probability of being active in $R \& D$ than small firms but, if they participate in $R \& D$, they spend less money relative to their sales in $\mathrm{R} \& \mathrm{D}$ compared to smaller firms.

Nevertheless, St-Pierre et al. [10] ${ }^{11}$, in their exploratory study of $288 \mathrm{manu}-$ facturing firms, reveal that the size and the age of the firm do not play a role of substitutable variables while the researchers conduct a study of SME performance, because the factors must take into account the size and age of the firm to have a clearer understanding of the behavior which many managements of SMEs are likely to avoid in developing their firms because of the lack of willingness.

$5 \quad$ Natarajan, B., et al., (2008): Firm age and innovation, Industrial and Corporate Change, 17, 5: 1019-1047.

6 Sorensen, J.B., Stuart, T.E., (2000): op. cit..

7 Mlouka, S.B., Sahut, J.M., (2008) : La taille est-elle un facteur déterminant de la compétitivité des entreprises, La Revue des Sciences de Gestion, 233, 5: 77-86

8 Cohen W.M., Klepper S., (1996): Firm size and the nature of innovation within industries: The case of process and product R\&D, Review of Economics and Statistics, 78: 232-243.

9 Kim, J.Y., Lee, S.J., Marschke, G., (2009): Relation of firm size to R\&D productivity, International Journal of Business and Economics, 8: 7-19.

10 Becker, J.P., et al., (2005): Innovation Effects of Science-Related Technological Opportunities: Theoretical Considerations and Empirical Findings for Firms in the German Manufacturing Industry, JahrbücherfürNationalökonomie und Statistik, 225. 2, 130-150

11 St-Pierre, J. et al., (2010) : L'effet de l'âge et de la taille sur la performance financière et économique des PME, Journal of Small Business \&Entrepreneurship, 23, 2 : 287-306. 


\subsection{From the Perspective of Patent}

Hall \&Ziedonis[11 $]^{12}$ and Merges $[12]^{13}$ find that stronger patent rights may have facilitated the entry of specialized firms and contributed to vertical disintegration.

Mairesse et al. $[1]^{14}$ present that if we look at the factors affecting R\&D intensity in the hi-tech sectorsafirm's size plays no significant role and, if significant, it has a small impact on the probability to innovate. In general size has no significant impact on the share of innovative sales. The effect of R\&D intensity on innovation is stronger than size, and more pronounced in hi-tech sectors.

Lee and Kim [13] ${ }^{15}$ summarize that a firm's patent activity represents the variation of propensity to patent with some empirical studies which try to find relationship between R\&D expenditure and patents (Kortum\& Lerner [14]; Vermeulen et al. [15]; Garcia-Vega [16]; Beneito [17]; Han and Lee [18]; Moreover, Brouwer and Kleinknecht [19], Cohen et al. [20] and Arundel and Kabla [21] ${ }^{16}$ suggest that high-tech firms are likely to have a higher propensity to patent than medium and low technological opportunity firms.

Scherer [22], Mansfield [23], Arundel and Kabla [21], Berger Consultants [24], Chabchoub and Niosi [25] $]^{17}$ show propensity to patent increases with the

12 Hall, B. H., Ziedonis. R. H., (2001): The patent paradox revisited: An empirical study of patenting in the U.S. semiconductor industry, 1979-1995, RAND Journal of Economics, 32(1): 101-128.

13 Merges, R.P., (1997), Patent Law and Policy. Charlottesville, VA: Michie.

14 Mairesse, J., et al., (2005) : op. cit.

15 Lee, Seong-Sang; Kim, Yeonbae. (2010): The impact of efficiency parameters on firms innovative activities: Evidence from Korean firm-level data, Innovation Management Policy \& Practice, 12, 3: 283-297.

16 Kortum, S., Lerner J., (2000): Assessing the contribution of venture capital to innovation, RAND Journal of Economics, 31: 674-692; Vermeulen, P.A.M., O’shaughnessy, K.C., De Jong, J.P.J., (2003): Innovation in SMEs: An empirical investigation of the input-throughputoutput-performance model, EIM Business \& Policy Research, Zoetermeer, The Netherlands; Garcia-Vega, M., (2006): Does technological diversification promote innovation? An empirical analysis for European firms, Research Policy, 35: 230-246; Beneito, P., (2006): The innovative performance of in-house and contracted R\&D in terms of patents and utility models, Research Policy, 35: 502-517; Han, Y.J., Lee, W.Y., (2007): The effects of the characteristics of Korean firms on the patent production function, Economics of Innovation and New Technology, 16: 293-301; Brouwer, E., Kleinknecht, A. (1999): Innovative output and a firm's propensity to patent: An exploration of CIS micro data, Research Policy, 28: 615-624; Cohen, W.M., Nelson, R.R., Walsh, J.P., (1998), Appropriability conditions and why firms patent and why they do not in the American manufacturing sector, Unpublished Working Paper, Carnegie Mellon University, Pittsburgh; Arundel, A., Kabla, I., (1998): What percentage of innovations are patented? Empirical estimates for European firms, Research Policy, 27: 127-141.

17 Scherer, F. M., (1999): New Perspectives on Economic Growth and Technological Innovation, Brookings, Washington. P188; Mansfield, E., (1986): Patents and innovation: An empirical study, Management Science, 32: 173-181; Berger Consultants, (1994), The use of patent protection in Europe: A representative survey committed by the European Patent Office, 
size of the firm because larger firms have a more complex research strategy and patenting is costly.

\subsection{The Perspective of Inter-firm \& Network and Leadership}

According to resource-based theory, technology cooperation is a mechanism by which firms use external technology and information to develop innovation capabilities dynamically. Eisenhardt\& Schoonhoven $[26]^{18}$ show that firms which have resources could get more resources. From the resource-based perspective, Miotti\&Sachwald [27] ${ }^{19}$ underscore that adequate partners should possess the resources which the firm is seeking. This partnership with right complementary resources is also highlighted by the Eisenhardt\& Schoonhoven $[26]^{20}$, Doz\& Hamel [28] ${ }^{21}$ and Mowery et al. [29] ${ }^{22}$.

Hagedoorn\&Schakenraad $[30]^{23}$ conclude that firm size reflects firm strategic linkages of how to seek and find external resources. Gulati $[31]^{24}$ presents that firm size is assumed to be indicative of a firm's economies of scale and resource self-sufficiency. Small firms are likely to make minimal use of alliances due to a lack of resources (Dickson and Weaver $[32]^{25}$ ). Shrader $[33]^{26}$ postulates that

EPOscript, München; Chabchoub N., Niosi J. (2005): Explaining the propensity to patent computer software, Technovation, 25: 971-978; Arundel, A., Kabla, I., (1998), What percentage of innovations are patented? Empirical estimates for European firms, Research Policy, 27: 127-141. Eisenhardt, K. M., Schoonhoven, C. B., (1996): Resource Based View of Strategic Alliance Formation: Strategic and Social Effects in Entrepreneurial Firms, Organization Science 7(2): $136-150$.

Miotti, L., Sachwald, F., (2003): Cooperative R\&D: Why and with Whom? An Integrated Framework of Analysis, Research Policy, 32: 1481-1499.

Eisenhardt, K. M., Schoonhoven, C. B., (1996): Resource Based View of Strategic Alliance Formation: Strategic and Social Effects in Entrepreneurial Firms, Organization Science 7(2): 136-150.

Doz, Y., Hamel, G., (1998), Alliance Advantage: The Art of Creating Value through Partnering, Boston, MA: Harvard Business School Press.

Mowery, D, Oxley, J, Silverman, B., (1998): Technological overlap and interfirm cooperation: implications for the resource-based view of the firm, Research Policy, 27: 507-523.

Hagedoorn, J., Schakenraad, J., (1994): The effect of strategic technology alliances on company performance, Strategic Management Journal, 15:291-309.

Gulati, R., (1993): The dynamics of alliance formation, doctoral dissertation, Harvard University, Cambridge, MA.

25 Dickson, P. H., Weaver, K.M., (1997): Environmental Determinants and Individual-Level Moderators of Alliance Use, Academy of Management Journal, 40, 2: 404-425.Shrader, R. C., (2001): Collaboration and performance in foreign markets: The case of young hightechnology manufacturing firms, Academy of Management Journal, 44 (3): 45-60.

26 Shrader, R. C., (2001): Collaboration and performance in foreign markets: The case of young high-technology manufacturing firms, Academy of Management Journal, 44 (3): 45-60. 
smaller firms may rely more on collaboration due to their limited resources, and that firm size influences the resources available, the strategies and performance. Zongling Xu et al. [34] ${ }^{27}$ conduct an empirical analysis of 92 SMEs in Shantou and suggest the interfirm reciprocity is correlated with innovative capabilities. Interfirm links could enhance the innovation capabilities in some important areas like "sources of information" and "access to information relevant to innovation".

Literature has been paying attention on in-house resources, and the employment of QSEs (qualified scientists and engineers) is one of the most important factors determining an SMEs propensity and ability to access external resources and innovate (Ritter and Gemunden [35]; Rothwell [36]; Cohen and Levinthal $\left.[37]^{28}\right)$. Bougrain\&Haudeville $[38]^{29}$ state that internal expertise facilitates the identification of external resources, their absorption and the improvement of SME's performance. Furthermore, Freeman $[39]^{30}$ highlights the importance of $\mathrm{R} \& \mathrm{D}$ intensity in recognizing and utilizing external resources.

The role of leadership is also presented in some studies: Miller [40] ${ }^{31}$ argues that the relationship between entrepreneurship and willingness of the owners to innovate is only uniformly significant in several types of enterprises. Bougrain and Haudeville $[38]^{32}$ find French companies with higher innovation ability should be affected by the managers' leadership style. Therefore, Yuan-Duen $[41]^{33}$ concludes that innovation ability is correlated with leadership style based on an empirical study of Taiwanese wire and cable companies. Eisenhardt\& Schoonhoven [26] $]^{34}$ believe that the factors of top managers, such as reputation, extensive connections and relationship with potential partners are the key source of leading firms to cooperate. Bougrain and Haudeville $[38]^{35}$ present that the managers' educational level

$27 \quad$ Zongling Xu, et al. (2008): Networking and innovation in SMEs: evidence from Guangdong Province, China, Journal of Small Business and Enterprise Development, 15, 4: 788-801.

28 Ritter, T., Gemünden, H.G., (2003): Network competence: its impact on innovation success and its antecedents, Journal of Business Research, 56: 745-55; Rothwell, R., (1991): External Networking and Innovation in Small and Medium-sized Manufacturing Firms in Europe, Technovation, 11, 2: 93-112; Cohen, W.M., D. Levinthal. (1989): Innovation and Learning: The Two Faces of R\&D, Economic Journal, 99: 569-596.

29 Bougrain, F., Haudeville, B., (2002): Innovation, Collaboration and SMEs Internal Research Capacities, Research Policy, 31:735-747.

30 Freeman, C., (1991): Networks of innovators: A synthesis, Research Policy, 20: 499-514.

31 Miller, D., (1983): The correlates of entrepreneurship in three types of firms, Management Science, 29, 7: 770-791.

32 Bougrain, F., Haudeville, B., (2002) : op. cit.

33 Yuan-Duen, L., (2006): Leadership style and innovation ability: An empirical study of Taiwanese wire and cable companies, Journal of American Academy of Business, 9(2): 218-222.

34 Eisenhardt, K. M., Schoonhoven, C. B., (1996), op. cit.

35 Bougrain, F., Haudeville, B., (2002) : op. cit. 
influences the scope of the network. Therefore, the managers' education level and managerial experiences should be considered as a supporting factor in this study.

\subsection{The Perspective of R\&D}

According to Chanaron et al. [42 $]^{36}$, a new systemic innovation management model is established from the perspective of $R \& D$, market pressure, culture mission, finance, and co-design/co-makership, based on the traditional model (Rada [43]; Morin [44] ${ }^{37}$ ) which emphasis that both external and internal $\mathrm{R} \& \mathrm{D}$ influence the innovation performance. Chanaron et al. $[42]^{38}$ conclude that higher levels of R\&D expenditure could lead the firms towards a more technologically dominated sector.

OECD [45] and Acs\&Audretsch [46] ${ }^{39}$ presented a model suggesting that innovative output is influenced by R\&D with an empirical study and found that the total number of innovations is positively related to $R \& D$.

Mairesse et al. $[1]^{40}$ show that R\&D is positively correlated with all measures of innovation output, and, all other things being equal, more correlated with size than innovation. Innovation is generally more sensitive to $R \& D$ in the low-tech sectors than in the high-tech ones.

In their quantitative research which takes into account $\mathrm{R} \& \mathrm{D}$ as a major factor, Zhang et al.[47] ${ }^{41}$ evaluate the growth abilities of 36 listed hi-tech SMEs in China with an index system, and conclude that the growth abilities of listed SMEs in China stay at a relatively low level with no significant differences among these SMEs. Based on an empirical study of 46 hi-tech SMEs in Beijing, Zhang [48] $]^{42}$ concludes that the R\&D expenditure is not correlated with the innovation capabil-

36 Chanaron, J.J., Birchall, D., Soderquist, K. (1996): Managing Innovation in SMEs, A Comparison of Companies in the UK, France and Portugal, International Journal of Technology Management, 12, 3: 291-305.

37 Rada, J.F., (1987): The Management of Technology, EFMD Colloquium on Technical Change, Geneva; Morin, J., (1985): L'excellencetechnologique, Publi-Union, Éditions J. Picollec.

38 Chanaron, J.J., Birchall, D., Soderquist, K. (1996): op.cit.

39 OECD and the Chinese Ministry of Science and Technology, (2007): OECD Reviews of Innovation Policy China Synthesis Report, Paris; Acs, Z.J., Audretsch, D.B., (1991): R\&D, firm size, and innovative activity, in Acs, Z.J., Audretsch, D.B., (Eds), Innovation and Technological Change: An international Comparison, Harvester Wheatsheaf, New York, NY.

$40 \quad$ Mairesse, J., et al., (2005) : op. cit.

${ }^{41}$ Zhang Yuming, et al. (2011): Study on the Evaluation and Prediction of ISME's Growthbased on data of Listed Companies in the Growth Enterprise Market, Journal of Shandong University, 5: 32-38 (in Chinese).

42 Zhang Haiyan (2008): Empirical Study on Performance Appraisal and R\&D Expenditure of hi-tech SMEs in China, Doctoral Thesis, Capital University of Economic and Business, Beijing. 
ity because most R\&D expenditureis of no effect and not turned into technology assets. Yet, the R\&D expenditure could bring great development for hi-tech SMEs.

\subsection{The Perspective of Profit and New Product}

Bradley et al.[49] $]^{43}$ show that innovation ensures that a firm enhances its performance, especially on profits. Creating new products keeps on satisfying customer desires. New products attract consumers while facing minimal competition, making the firm to retain market leadership in terms of profitability. Even if profitability in new products may not be maintained in the long run, a firm that consistently introduces new products is able to maintain high performance. Kim \& Huang [50] ${ }^{44}$ note that innovations can be accomplished through development of new products in the market that increases a firm's leverage through increased profits and consumer satisfaction.

\subsection{Gaps in the Literature}

All these above mentioned perspectives could jointly explain the issues of innovation capabilities. However, any one of these perspectives on its own is not sufficient to fully reply the research question. Therefore, a questionnaire combining all the factors from every perspective will be proposed in the next chapter.

Chanaron et al. [42] ${ }^{45}$ designed a questionnaire inspired by Waterman and Kirk [51] ${ }^{46}$ and trailed in 1993 within the Thames Valley. The critical factors are proposed and aspects of business investigated such as company profitability, investment in $\mathrm{R} \& \mathrm{D}$, principal markets and their anticipated development, general conditions in their principal business sector, drivers for change, measures to improve short term profitability (importance and performance), measures to ensure long-term well-being (importance and satisfaction with response), sources of innovation in product/service procedures (considering a recent successful and significant innovation), sources of innovation in processes and procedures (considering a recent successful and significant innovation), the organization in general - issues such as structure and management, innovation strategy, innovation culture, market approach, etc.

Although previous research has covered somewhat varying perspectives, the overarching theme requires a series of specific critical factors. However, some factors seem to be easy to transform into survey questions but very difficult to be collected due to the difficulties of understanding on these terms. Therefore, with

43 Bradley, S.W., et al., (2012): Capital Is Not Enough: Innovation in Developing Economies, Journal of Management Studies, 49, 4: 684-717.

44 Kim, S., Huang, K. H., (2011): Winning strategies for innovation and high-technology products management, Journal of Business Research, 64(11): 1147-1150.

45 Chanaron, J.J., Birchall, D., Soderquist, K. (1996):op.cit.

46 Waterman N., Kirk M., (1992): The Innovation Management Tool Kit, in Bowen A., Ricketts M. Stimulating in Industry, The Challenge for the United Kingdom, NEDO, London 
respect to the questionnaire, to facilitate the comprehension of all the questions in the survey, a pilot study should be conducted so as to test each question. In that way the matter at handcould be understood and a response could be given more easily. Eventually, the study should delete or modify the questions which are likely to confuse the respondents or which are too complicated to figure out.

This chapter highlights a literature review covering hi-tech SMEs through four major sections: innovation, hi-tech SMEs, theories of SME innovation and an evaluation of the innovation capabilities. Following all the theories, the definition of innovation, imitation and hi-tech SMEs are chosen to facilitate the following study in the next chapter. As with all literature, further study is required to identify the gaps in the literature followed by careful evaluation of the information gathered from all the academic resources. In this study, this chapter points out that research is incomplete in empirical comparative study in innovation capabilities of hi-tech SMEs in China.

Yet, according to all the argument of studies, the relationship between some specific factors and innovation capabilities remain unproven.

Firstly, Kim [52] and Okimoto [53 $]^{47}$ suggest that firms' size has been positively correlated with the innovation stage in less developed countries like Japan and Korea over the past decades, and the same could be deduced about China. On the other hand, Leonard-Barton $[54]^{48}$, Sorensen and Stuart $[4]^{49}$ found that firm age has a negative effect on innovation. Natarajan et al. [5] reveal that firm age is negatively related to innovation and this effect is greater in the area of technology. However, Sorensen and Stuart [4] find that firm age is negatively related to innovation capabilities in semiconductors but positively so in biotechnology. Mlouka et al. [6], Cohen \& Klepper [7]; Kim et al. [8], Becker et al. [9], St-Pierre et al. $[10]^{50}$ etc. found different relationships between firm size/age and innovation capabilities from many variable perspectives. Thus, it remains unclear whether a conclusion could be drawn about the firm age/size and the innovation stages.

Secondly, although Chanaron et al. [42], OECD [45], Acs\&Audretsch [46], Mairesse et al. $[1]^{51}$ prove that $\mathrm{R} \& \mathrm{D}$ is positively correlated with all measures of innovation output and more correlated to size than innovation, some Chinese

47 Kim Linsu, (1997): Imitation to Innovation, Harvard Business School Press, Boston; Okimoto, D., Saxonhouse, G., (1987): Technology and the Future of the Economy, in Yamamura, K., Yasuba, Y., Eds, (1987), The Political Economy of Japan, 385-419, Stanford, Stanford University Press.

48 Leonard-Barton, D., (1992): Core Capabilities and Core Rigidities: A Paradox in Managing New Product Development, Strategic Management Journal, 13: 111-125.

49 Sorensen, J.B., Stuart, T.E., (2000): op. cit.

50 Mlouka, S.B., Sahut, J.M., (2008): Cohen W.M., Klepper S., (1996): Kim, J.Y., Lee, S.J., Marschke, G., (2009): Becker, J.P., et al., (2005): St-Pierre, J. et al., (2010): op. cit.

51 Chanaron, J.J., Birchall, D., Soderquist, K. (1996): OECD and the Chinese Ministry of Science and Technology, (2007): Acs, Z.J., Audretsch, D.B., (1991): op.cit. 
researchers, like Zhang et al. [47] and Zhang [48] ${ }^{52}$ analyze, in their quantitative researches, the growth abilities of 36 listed hi-tech SMEs in China with an index system, and conclude that the R\&D expenditure is not correlated with the innovation capability because most part of R\&D expenditure is of no effect and not turned into technology assets. The relationship between the innovation stage and $R \& D$ expenditure remains unclear in the literature.

Thirdly, with regards to patents, the literature demonstrates that high-tech firms have a higher likelihood to patent than medium and low technological opportunity firms. According many scholars, the filed patents could be considered as a main factor. Because the two variables, the filed patent and granted patent are significantly correlated in the model, this paper adopts the later variable as a key factor. This factor should be specially discussed in next chapter with an empirical study in China.

Fourthly, many studies have found that innovative capabilities ensure that a firm enhances firm performance, especially on profits. Nevertheless, a confirmation with quantitative research should be conducted to support the same theory in hi-tech SMEs, which could not be found in the literature.

Finally, the other factors such as inter-firm relationship, new products, attitude of involvement in innovation, education level and managerial experiences, which are likely to positively correlate with innovation stage, also need to be verified in this study. Because of the specificity of sampling and data collecting issues, the results should be analyzed using a quantitative analysis.

All these above factors work together to explain the issues related to innovation capabilities. Any one of these perspective on its own is not sufficient to fully explain the research question. A questionnaire combining all the factors from every perspective has to be conducted.

Furthermore, none of the measures of innovation capabilities is entirely satisfactory since they are based on diverging theories. None of these studies have been conducted recently using empirical data in China and the China hi-tech SMEs innovation situation has been changing rapidly. Due to these reasons, it is necessary to raise several questions and reconsider and re-examine the hi-tech SMEs innovation capabilities in China. Meanwhile, some elements should be chosen as basic factors to conduct the empirical study, which is presented in the next chapter.

Therefore, based on the previous discussion, this study considers ' $R \& D$ expenditure intensity', 'firm age', 'firm size', 'innovation stage', 'profit intensity', 'new product intensity', 'number of cooperative projects', 'granted patent intensity', 'the attitude of involvement in innovation activities', 'the education level' and 'the managerial experiences', etc. as proxies of innovation capabilities.

52 Zhang Yuming, et al. (2011) : Zhang Haiyan (2008) : op.cit. 


\section{Research Hypotheses}

According to the tripartite treatment of the Schumpeterian innovation stages (Chanaron and Metcalfe, $[55]^{53}$ ), the SME's age and size are correlated with the main innovation stages: invention, innovation or imitation. This paper focuses on distinguishing the differences in the main innovation processes according to a survey in Hi-tech SMEs in China and in France. Hypotheses are derived from the theory.

Firstly, according to this tripartite classification of events encapsulating, "the forces shaping the process of imitation are distinct from those shaping invention and innovation". Literature in business strategy suggests that firms of different ages and sizes pursue different technology strategies which have an impact on their innovation capabilities. Kim $[50]^{54}$ and Okimoto\&Saxonhouse $[53]^{55}$ found that by learning through the imitation of foreign ideas and techniques while the firm's size is still small, less developed countries like Korea and Japan had promoted technological change to help them catch up with developed countries in the past decade. According to these literature reviews, it is likely that China SMEs would continue to follow the same processes as their neighbors, Japan and Korea. To have an in-depth insight into the actual innovation situation in China, the study conducts the analysis of innovation stage of firms in general by size. Furthermore, because the firm's age is statistically relative with the growth of the firms in size, an effect of the firms' age could also be hypothesized.

Therefore, two hypotheses are proposed as follows:

- Hypothesis 1a: The hi-tech SMEs' age is positively correlated with the innovation stage of hi-tech SMEs.

- Hypothesis 1b: The hi-tech SMEs' size is positively correlated with the innovation stage of hi-tech SMEs.

Secondly, following to Chanaron et al. $[42]^{56}$, the higher levels of expenditure R\&D could lead the firms towards a more technologically dominated sector. OECD [45] and Acs\&Audretsch [46] ${ }^{57}$ present a model suggesting that innovative output is influenced by $R \& D$ with an empirical study and find that the total number of innovations is positively related to R\&D. Mairesse et al. $[1]^{58}$ present

53 Chanaron, J.J., Metcalfe, J. S., (1990) : L'économie schumpétérienne, Technologies, Idéologies et Pratiques, IX, 1: 73-91.

54 Kim, S., Huang, K. H., (2011): op.cit.

55 Kim, S., Huang, K. H., (2011): Okimoto, D., Saxonhouse, G., (1987): op.cit.

56 Chanaron, J.J., Birchall, D., Soderquist, K. (1996): op.cit.

57 OECD and the Chinese Ministry of Science and Technology, (2007): Acs, Z.J., Audretsch, D.B., (1991): op. cit.

$58 \quad$ Mairesse, J., et al., (2005) : op. cit. 
that $\mathrm{R} \& \mathrm{D}$ is positively correlated with all measures of innovation output, and, all other things being equal, more correlated to size than innovation. Innovation is generally more sensitive to R\&D in the low-tech sectors than in the high-tech sectors. If we look at the determinants of $\mathrm{R} \& \mathrm{D}$ intensity, in the hi-tech sectors, afirm's size plays no significant role and, if significant, it has a small impact on the probability to innovate. Size has, in general, no significant impact on the share of innovative sales. The effect of $\mathrm{R} \& \mathrm{D}$ intensity on innovation is stronger than size and more pronounced in the hi-tech sectors. According to the literature, it is suggested that the R\&D expenditure intensity is correlated with the innovation capabilities and innovation stage.

Therefore, a hypothesis is proposed as follows:

- Hypothesis 2: The R\&D expenditure intensity is positively correlated with the innovation stage.

Thirdly, in the early empirical research, Narin et al. [57 ${ }^{59}$ suggest that the innovation and number of granted patents have no correlation with financial performance. However, Bradley et al. [49] ${ }^{60}$ found that innovation ensures that a firm enhances its performance, especially on profits. Creating new products keeps satisfying customers' desires. New products attract consumers while facing minimal competition, helping the firm to retain market leadership in terms of profitability. Even if profitability in new products may not be maintained in the long run, a firm that consistently introduces new products is able to maintain high performance. Kim \& Huang $[50]^{61}$ note that innovations can be accomplished through development of new products in the market that increases a firm's leverage through increased profits and consumer satisfaction.

Thus, two hypotheses could be proposed as follows:

- Hypothesis 3: The profit intensity is positively correlated with the innovation stage.

- Hypothesis 4: New product intensity is positively correlated with the innovation stage.

Fourthly, Eisenhardt et al. [26] ${ }^{62}$ show that firms which have resources could get resources. From the resource-based perspective, Miotti\&Sachwald [27] ${ }^{63}$ underscore the adequate partners should possess the resources which the firm

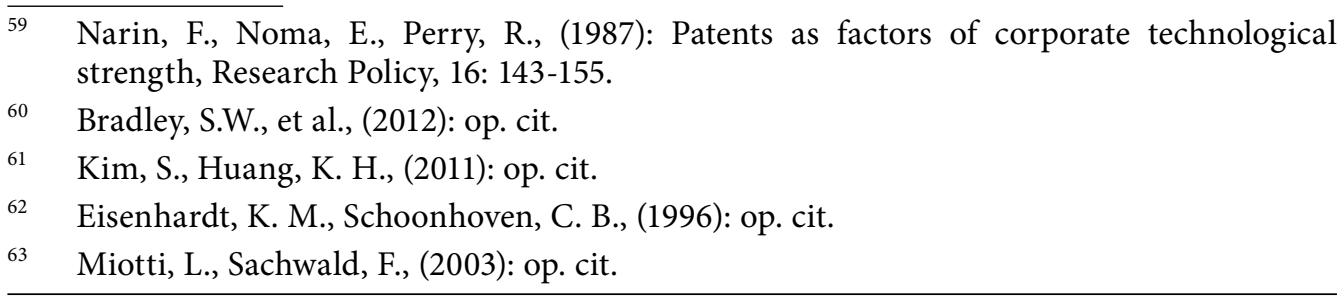


is seeking. This partnership with the right complementary resources is also suggested by the Eisenhardt et al. [26], Doz et al. [28] and Mowery, Oxley \& Silverman [29]. Hagedoorn et al. [30] ${ }^{64}$ conclude that firm size reflects firm strategic links in how to seek and find external resources. Gulati $[31]^{65}$ claims that firm's size is assumed to be indicative of a firm's economies of scale and resource sufficiency. Small firms are likely to make alliances using minimal resources (Dickson \& Weaver, [32]. Shrader $[33]^{66}$ proposes that smaller firms may rely more on collaboration due to their limited resources, and firm size influences the resources available, the strategies and performance. Thus, technology cooperation might be a mechanism by which firms use external technology and information to develop innovation capabilities. It is necessary to establish a hypothesis to verify this resource-based theory.

Therefore, a hypothesis is proposed as follows:

- Hypothesis 5: The collaborative R\&D relationship is positively correlated with innovation stage.

Fifthly, Hall \&Ziedonis [11] and Merges $[12]^{67}$ find that stronger patent rights may have facilitated entry by specialized firms and contributed to vertical disintegration. Lee and Kim $[13]^{68}$ summarize that a firm's patenting activity represents the variation of propensity to patent with some empirical studies which try to find relationship between R\&D expenditure and patent (Kortum\& Lerner [14]; Vermeulen et al. [15]; Garcia-Vega [16]; Beneito [17]; Han and Lee [18]); Moreover, Brouwer and Kleinknecht [19], Cohen et al. [20] and Arundel and Kabla [21] ${ }^{69}$ showed that high-tech firms are likely to have a higher propensity to patent than medium and low technological opportunity firms.

Therefore, a hypothesis should be proposed as follows:

- Hypothesis 6: The number of granted patents is positively correlated with the innovation stage.

64 Eisenhardt, K. M., Schoonhoven, C. B., (1996): Doz, Y., Hamel, G., (1998): Mowery, D, Oxley, J, Silverman, B., (1998): Hagedoorn, J., Schakenraad, J., (1994): op. cit.

65 Gulati, R., (1993): op. cit.

66 Dickson, P. H., Weaver, K.M., (1997); Shrader, R. C., (2001): op. cit.

67 Hall, B. H., Ziedonis. R. H., (2001): Merges, R.P., (1997): op. it.

68 Lee, Seong-Sang; Kim, Yeonbae. (2010):op.cit.

69 Kortum, S., Lerner J., (2000): Vermeulen, P.A.M., O’shaughnessy, K.C., De Jong, J.P.J., (2003): Garcia-Vega, M., (2006): Beneito, P., (2006): Han, Y.J., Lee, W.Y., (2007): Brouwer, E., Kleinknecht, A. (1999): Cohen, W.M., Nelson, R.R., Walsh, J.P., (1998): Arundel, A., Kabla, I., (1998): op. cit. 
Finally, Trompenaars $[58]^{70}$ suggests that "western analytical thinking and rationality have led to many international successes in fields of technology". Fukuyama [59] ${ }^{71}$ shows that low degree of trust weakens the ability of Chinese to innovate. Nisbett $[60]^{72}$ reveals that Chinese are likely to be less innovative than their counterparts in Western firms due to the Chinese characteristic of lack of curiosity. Mueller et al. $[61]^{73}$ present that "an innovative orientation is more likely in individualistic cultures and less likely in collectivistic cultures". Since the Chinese have collectivistic cultures, they are most likely to be less innovative than their counterparts in Western companies who have individualistic cultures. Van et al. [62] and Hofstede et al. $[63]^{74}$ found that cultural variables have significant impact on the adoption of innovations. Previous researches demonstrate that different national cultures could have influence on the attitude of managers in different countries to innovate. In addition, Miller [40] argues that the relationship between entrepreneurship and the attitude of owners towards innovation is only significant in several types of enterprises. Bougrain and Haudeville $[38]^{75}$ found that French companies with higher innovation ability should be affected by the managers' leadership style. Moreover, Yuan-Duen $[41]^{76}$ concludes that innovation ability is correlated with leadership style based on an empirical study of Taiwanese wire and cable companies. Eisenhardt et al. [26] ${ }^{77}$ believe that the factors of top managers, such as reputation, managerial experiences, extensive connections and relationship with potential partnering firm, is the key source of leading firms to cooperate. Bougrain and Haudeville $[38]^{78}$ present that the managers' educational level influences the scope of the network. Therefore, the managers' attitude to innovation, the managers' education level and managerial experiences should be considered as supporting factor in this study.

Therefore, the following hypothesis should be proposed:

$70 \quad$ Trompenaars, F., (1994): Riding the Waves of Culture: Understanding Diversity in Global Business, Irwin Professional Publishing, Burr Ridge, IL.

71 Fukuyama, F., (1995): Trust: The Social Virtues and the Creation of Prosperity, The Free Press, New York, NY.

72 Nisbett, R.E., (2003): The geography of thought: How Asians and Westerners think differently and why, New York: Free Press.

73 Mueller, S., Thomas, A., (2001): Culture and entrepreneurial potential: a nine country study of locus of control and innovativeness, Journal of Business Venturing, 16, 1: 51-75.

74 Van Everdingen, Y.M., Waarts, E., (2003): The effect of national culture on the adoption of innovations, Marketing Letters, 14, 3: 217-232 ; Hofstede, G. et al., (2005): Cultures and Organizations: Software of the Mind, 2nd Edition, McGraw-Hill USA, 2005.

75 Bougrain, F., Haudeville, B., (2002) : op. cit.

76 Yuan-Duen, L., (2006): op.cit.

77 Eisenhardt, K. M., Schoonhoven, C. B., (1996): op. cit.

78 Bougrain, F., Haudeville, B., (2002) : op. cit. 
- Hypothesis 7: The innovation influence of an entrepreneur, such as managers' education level, managerial experience and attitude to involvement innovation, etc., is positively correlated with the innovation stage.

Following Chen and Pan $[64]^{79}$, conducting a linear regression analysis between China and 49 other countries with R\&D expenditure intensity, the number of granted patents, new products intensity, firms profits intensity and so on from 1991 to 2007, concluded that there is an important difference in innovation capabilities between China and France, positioning China at the40th place, whilst France was the $7^{\text {th }}$ in a total of 50 countries. Moreover, Zhao et al. $[65]^{80}$ argue that Chinese firms have consolidated their production capacity and technological learning but are rarely in the position to develop an innovation capability and the real innovation system does not exist in China. The small size of enterprises in China are less supported by government policies and have difficulties in obtaining subsidies for training, higher education, research, technical centers, and finance aide etc. This separation of the innovation system promoted by the government and the industrial system is the main reason for a low innovation capability of the Chinese industry. The co-existence of these two different modes is a characteristic feature in China and explains why China does not follow the innovation stage of "imitation to innovation" experienced by South Korea and Japan.

Therefore, a hypothesis would be presented:

- Hypothesis 8: The difference in innovation capabilities between China and France is statistically significant.

The relationship among the factors and hypotheses is listed in the following figures.

79 Chen Xinfang and Pan Xinlu, (2010): Research on Innovation and International Competitive Capability, China National Natural Science Foundation of China (NSFC)'s Program (Project No.: 70573096), China Science Press, Beijing.

80 Zhao, W., Arvanitis R., (2008): The Unequal Development of China: Innovation Capabilities and the Co-existence of Different Industry Growth Patterns, Région et Développement, 28: 61-85. 


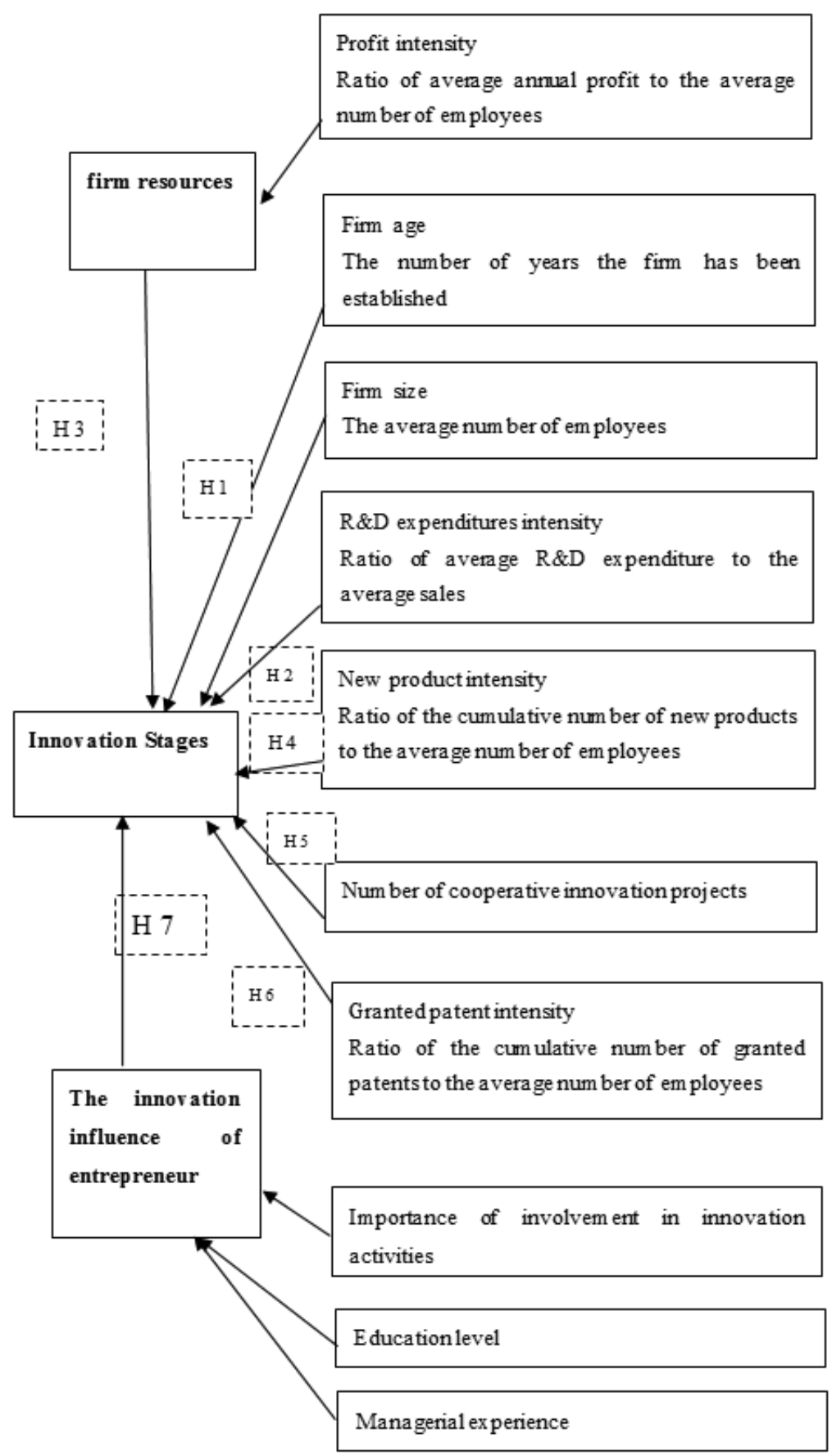

Figure 1. The hypotheses and the factors 


\section{Research Design and Methodology}

This research aims at comparing French SMEs and Chinese SMEs. However, the two countries have distinct classifications of SMEs. The definition of SMEs in China is relatively complicated and based not only on the number of employees but also on annual revenue and total assets and above all varies with the industry. This article uses the number of 250 employees to classify sample firm's size so as to accord with the standard of Europe and make the data more comparable and reliable. Because this study focuses on hi-tech SMEs which are technology-intensive rather than labor-intensive, the disadvantage of this approach should not be a limitation for the applicability of the research results.

Table 1. Examples of the Classification Standards of SMEs in China in 2011

\begin{tabular}{|c|c|c|c|c|c|}
\hline Industry & Specific standard & Units & Medium & Small & Micro \\
\hline Heavy industry & Number of employees $(X)$ & person & $300 \leq X<1000$ & $20 \leq X<300$ & $X<20$ \\
\hline Wholesale trade & Number of employees $(X)$ & person & $20 \leq X<200$ & $5 \leq X<20$ & $X v 5$ \\
\hline Retail industry & Number of employees $(X)$ & person & $50 \leq X<300$ & $10 \leq X<50$ & $X<10$ \\
\hline Transportation industry & Number of employees $(X)$ & person & $300 \leq X<1000$ & $20 \leq X<300$ & $X<20$ \\
\hline $\begin{array}{c}\text { Restaurant and catering } \\
\text { industry }\end{array}$ & Number of employees $(X)$ & person & $100 \leq X<300$ & $10 \leq X<100$ & $X<10$ \\
\hline $\begin{array}{c}\text { Information transmission } \\
\text { industry }\end{array}$ & Number of employees $(X)$ & person & $100 \leq X<2000$ & $10 \leq X<100$ & $X<10$ \\
\hline Software and IT service & Number of employees $(X)$ & person & $100 \leq X<300$ & $10 \leq X<100$ & $X<10$ \\
\hline $\begin{array}{c}\text { Property management } \\
\text { industry }\end{array}$ & Number of employees $(X)$ & person & $300 \leq X<1000$ & $100 \leq X<300$ & $X<100$ \\
\hline \begin{tabular}{c} 
Nof \\
\hline
\end{tabular}
\end{tabular}

In order to ease the comparison between French and Chinese hi-tech SMEs, the definition of National Bureau of Statistics of China $[66]^{81}$ which coincides with OECD's classification is adopted. Considering the scale of the population of SMEs, the regions of the survey have been narrowed down. According to INSEE $[67]^{82}, 57 \%$ SMEs in Rhône-Alpes had innovation activities from 2008 to 2010, which is $3 \%$ higher than the national average in France. In China, R\&D intensity remains heavily concentrated in some regions, notably Beijing, Shanghai, Jiangsu, Guangdong and Zhejiang (CNBS [66]; OECD [45] $]^{83}$. Hi-tech firms in Shanghai and in Rhône-Alpes situated in dynamic zones benefit not only

\footnotetext{
81 China National Bureau of Statistics, (2009): China Statistics Yearbook on hi-tech technology industry, Beijing.

82 INSEE, (2012) : Les PME de Rhône-Alpes innovent pour se développer, Analysis Report $\mathrm{N}^{\circ}$ 180 , novembre.

83 China National Bureau of Statistics, (2009); OECD and the Chinese Ministry of Science and Technology, (2007): op. cit.
} 
from favorable policies and services provided by the government, but also the networks of universities, national research institutes and cluster of hi-tech firms $(\text { Chanaron, Scaringella [68] })^{84}$.

The European Commission recommendation specifies a method of establishing and calculating reference data. Enterprises qualify as micro, small or medium-sized enterprises if they fulfill maximum ceilings for staff headcount and either a turnover ceiling or a balance sheet ceiling (see table 1 below).

Table 2. The new thresholds implemented by the European Commission in 2003

\begin{tabular}{|c|c|c|c|}
\hline Enterprise Category & Staff headcount & Annual Turnover & Annual Balance Sheet Total \\
\hline Medium-sized & $<250$ & $\leq € 50$ million & $\leq € 43$ million \\
\hline Small & $<50$ & $\leq € 10$ million & $\leq € 10$ million \\
\hline Micro & $<10$ & $\leq € 2$ million & $\leq € 2$ million \\
\hline
\end{tabular}

Source: European Commission $[69]^{85}$.

The research is based on a model of deductive research (Zikmund [70]; Bryman [71] $)^{86}$. According to these two authors, a deductive study deduces hypotheses and logic processes using empirical observation to derive a conclusion from a known premise, with the objective to first verify the theories then to develop or expand the theories.

\subsection{Pilot Study and Data collection}

This research used a pilot study to try out and refine survey questions with a small sample of hi-tech SMEs in China and in France before sending the formal questionnaire to a large sample.

During the pilot study, five face-to-face interviews and five telephone interviews were conducted early 2012. The researcher presented the questionnaire to managers, observed their feedback and asked for their comments after filling out the forms. After the pilot test on this small number of firms, several details of questions were modified so as to ensure that respondents would have less difficulty in understanding and answering the questionnaire. The questionnaire was

84 Chanaron, J.J., Scaringella, L., (2016): Grenoble-GIANT Territorial Innovation Models: Are investments in research infrastructures worthwhile?, Technological Forecasting \& Social Change, 112: 92-101.

85 European Commission, (2009): Commission Staff Working Document on the implementation of Commission Recommendation of 6 May 2003 concerning the definition of micro, small and medium-sized enterprises, Brussels.

86 Zikmund, W.G., (1991): Exploring Marketing Research, International edition, Dryden Press, Orlando, FL; Bryman, A. (2004), Social research methods (2nd ed.), Melbourne: Oxford University Press. 
subsequently sent to twenty selected companies so as to develop the pilot study in May 2012 and 90\% valid responses were returned.

This pilot study demonstrates that the data collection could work smoothly if the respondents would reply to the questionnaire positively and in a timely manner, which is helpful to confirm the content validity of the questions in the instrument.

The pilot study also revealed that each interview would take more than 40 minutes, sometimes more than one hour. It was decided to use only written questionnaire.

According to Chanaron et al. [42] ${ }^{87}$, the response rate to questionnaires of SMEs in Europe is relatively low. The reasons why managers of SMEs are unlikely to reply to the questionnaire are complicated. For example, SMEs that are likely to be family business would not be willing to reveal their firms data. Moreover, the data could not be found in public documents.

When selecting the firms in the two regions, it was decided to carefully respect the same percentage of different industries according to the OECD's classification.

A total of 2,523 questionnaires were sent to French and Chinese enterprises. However, 192 returned questionnaires were finally collected.

Table 3. The new thresholds implemented by the European Commission in 2009

\begin{tabular}{|c|c|c|c|c|c|}
\hline Area & $\begin{array}{c}\text { Targeted } \\
\text { Populations }\end{array}$ & $\begin{array}{c}\text { Disseminated } \\
\text { questionnaires }\end{array}$ & $\begin{array}{c}\text { Received } \\
\text { questionnaires }\end{array}$ & $\begin{array}{c}\text { Valid } \\
\text { questionnaires }\end{array}$ & Return rate \\
\hline Shanghai in China & 40,000 & 1,220 & 101 & 95 & $7.8 \%$ \\
\hline Rhône-Alpes in France & 40,000 & 1,303 & 113 & 97 & $7.4 \%$ \\
\hline
\end{tabular}

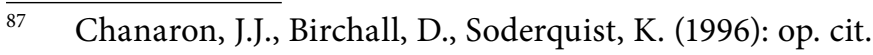




\subsection{Data Analysis}

Table 4.Personal profile of respondents in China and in France

\begin{tabular}{|c|c|c|c|c|c|}
\hline Variable & Category & $\begin{array}{l}\text { Number } \\
\text { in China }\end{array}$ & $\begin{array}{l}\text { Percentage } \\
\text { in China }\end{array}$ & $\begin{array}{c}\text { Number in } \\
\text { France }\end{array}$ & $\begin{array}{c}\text { Percentage } \\
\text { in France }\end{array}$ \\
\hline \multirow{4}{*}{$\begin{array}{l}\text { Managers' age } \\
\qquad(\mathrm{N}=97)\end{array}$} & 30 and below & 21 & $21.6 \%$ & 6 & $6.1 \%$ \\
\hline & $31-40$ & 46 & $47.5 \%$ & 17 & $18.1 \%$ \\
\hline & $41-50$ & 19 & $19.6 \%$ & 41 & $43.5 \%$ \\
\hline & 51 and more & 11 & $11.3 \%$ & 35 & $35.4 \%$ \\
\hline \multirow{2}{*}{$\begin{array}{l}\text { Managers' gender } \\
(\mathrm{N}=91)\end{array}$} & male & 85 & $93.4 \%$ & 98 & $98 \%$ \\
\hline & female & 6 & $6.6 \%$ & 2 & $2 \%$ \\
\hline \multirow{5}{*}{$\begin{array}{l}\text { Managers' } \\
\text { education level } \\
\qquad(\mathrm{N}=97)\end{array}$} & High school and below & 2 & $2.1 \%$ & 10 & $10.1 \%$ \\
\hline & $\mathrm{Bac}+3$ & 18 & $18.5 \%$ & 25 & $25.3 \%$ \\
\hline & College or university Bac+4 & 57 & $58.8 \%$ & 3 & $3.0 \%$ \\
\hline & Master & 17 & $17.5 \%$ & 50 & $50.5 \%$ \\
\hline & Doctor & 3 & $3.1 \%$ & 11 & $11.1 \%$ \\
\hline \multirow{6}{*}{$\begin{array}{c}\text { Managers' } \\
\text { managerial } \\
\text { experience (year) } \\
\quad(\mathrm{N}=97)\end{array}$} & 4 and less & 27 & $27.8 \%$ & 9 & $9.3 \%$ \\
\hline & $5-10$ & 37 & $39.2 \%$ & 18 & $18.5 \%$ \\
\hline & $11-15$ & 17 & $17.6 \%$ & 23 & $23.7 \%$ \\
\hline & $16-20$ & 7 & $7.2 \%$ & 18 & $18.6 \%$ \\
\hline & $21-25$ & 2 & $2.1 \%$ & 17 & $17.4 \%$ \\
\hline & 25 and more & 7 & $7.2 \%$ & 12 & $12.4 \%$ \\
\hline \multirow{2}{*}{$\begin{array}{c}\text { Managers' } \\
\text { foundership ( } N=97)\end{array}$} & Founder & 55 & $56.7 \%$ & 64 & $64.6 \%$ \\
\hline & Not a founder & 42 & $43.3 \%$ & 35 & $35.4 \%$ \\
\hline
\end{tabular}

According to the questionnaires, the Chinese managers are typically much younger than French managers. There is no difference in managers' gender in two countries. However, most Chinese managers graduate from university with bachelor degrees whilst most French managers come from graduate school with master degrees. Moreover, Chinese managers' managerial experience is typically shorter than French managerial experience: $67 \%$ of Chinese managers have less than 10 years' experience, compared to only $28 \%$ for French managers. The difference of foundership between the two countries is not significant. The questionnaires show that most Chinese firms are less than 10 years old. On the contrary, most French firms are more than 10 years old. In both countries most hi-tech SMEs have less than 29 employees. Sales intensity and profit intensity in France are much higher than those in China.

The survey presents significant differences between the two countries. More than $43 \%$ firms in France are likely to engage in the innovation and invention stage compared with only $5.2 \%$ firms in China. French managers are likely to 
think it more important to involve in the innovation activities during the next 10 years.

In order to distinguish whether there are differences in the resources for innovation capabilities between French and Chinese firms, a mean difference analysis was conducted using the variables 'manager's education level', 'management experience', 'firm age', 'firm size', 'R\&D expenditure intensity', 'new product intensity', 'cooperative intensity', 'filed patents intensity', 'granted patents intensity', 'sales intensity' and 'profit intensity'. The independent-samples t-test was conducted to examine the mean differences between the two groups of firms.

The results suggest that there are significant differences between China and France in 'management experience', 'firm age', 'firm size', 'new product intensity', 'filed patent', 'granted patent', 'sales intensity' and 'profit intensity'. However, no significant difference was found of 5\% level in the responses to 'education level', ' $\mathrm{R} \& \mathrm{D}$ expenditure intensity', and 'cooperative intensity'.

The means on the factor 'education level' varied between the two countries (China 3.01, France 3.28). Nevertheless, the difference is not significant. This would suggest that executives in each country have a similar education level.

The managerial experience differed between the two countries, which shows that the French managers are likely to have much more experience than their Chinese counterparts. This point could also explain why the firm's age in China seems to be significantly shorter than the firms' age in France, since most managers in both countries are the founders of the firms.

The size of the firms is obviously different. Hi-tech SMEs in China are significantly larger than those in France. R\&D expenditure intensity in France shows no significant difference from that in China. Since the sales in French firms are typically larger than those in Chinese firms, the R\&D expenditure in France is also larger than that in China. New product intensity in China is considerably lower than in France, which means that the new product per employee in French hi-tech SMEs is significantly larger. Meanwhile, cooperative project intensity is not a factor that shows any difference between China and France. The filed patent, granted patent, sales intensity and profit intensity all show a significant difference between the two countries.

Field $[72]^{88}$ presents a method of identifying multi-collinearity using the VIF (variance inflation factor) to indicate whether a predictor has a strong linear relationship with other predictors. After conducting a SPSS linear regression colliearity test, all the values of VIF are less than 3. According to Myers [73] ${ }^{89}$, no multi-collinearity might be biasing the regression model in this paper.

$88 \quad$ Field A., (2009): Discovering Statistics using IBM SPSS Statistics, SAGE.

89 Myers, R. H., (1990): Classical and Modern Regression with Applications, PWS-Kent Publishing Company 
The questionnaire provides some descriptive statistics and the Pearson correlation coefficients between the two countries, and shows some variables discussed. Between independent variables, 24 correlation coefficients are significant but none are above 0.70 , which means that the assumption of multi-collinearity is not violated (Tabachnick and Fidell $[74]^{90}$ ). Therefore, a linear regression could be undertaken.

\subsection{Linear Regression Analysis of the Variables}

The following model is proposed: the model covers all the variables including the country variable that distinguishes the two countries with a dummy variable. Firms belonging to China have the country value $=$ ' 1 ', while firms belonging to France have the country value $=$ ' 0 '. This value indicates how China differs from France with respect to the research question.

According to the hypotheses in chapter 3.2, the regression equations could be introduced in one linear combination:

Table 4 presents the results concerning the regression equation: the regression model is significant $(\mathrm{F}(11,134)=28.395, \mathrm{p}=0.000)$. The independent variables predict $70.0 \%$ of the variance in the dependent variable.

There is a significant negative relationship between the country and innovation stage (beta $=-0.420$, sig=.000), which means the difference between China and France is significant and the French firms might have more innovation resources.

According to the regression results, the independent variables such as country, managerial years, granted patents intensity, firm size, R\&D expenditure intensity, new product intensity, profit intensity and managers' attitude and cooperative projects' intensity, are positively correlated with the innovation stage. Nevertheless, the independent variables such as the firm's age and education level are not significantly positively correlated with innovation stage, implying that hypotheses H1a and H7a are not supported.

90 Tabachnick, B.G., Fidell, L.S., (1996): Using Multivariate Statistics, 3rd, New York, HarperCollins. 
Regression equation

Innovation-stage $=$ Constant $1+$ C10Country (Question) + C11aAge $(\mathrm{H} 1 \mathrm{a})+$ C11bSize (H1b) + C21R\&D_Expenditure_intensity (H2)+ C31Profit_intensity (H3)+C41New_product_intensity (H4) + C51Cooperative_projects (H5)+ C61Granted_Patent (H6)+C71aattitude_of_involvement (H7a)+C71bEducation_level(H7b)+C71cManagement_experience(H7c)+ Random Error1

Innovation-stage $=$ Constant 1

+ C10Country (Question)

+ C11aAge (H1a)

$+\mathrm{C} 11 \mathrm{bSize}(\mathrm{H} 1 \mathrm{~b})$

+C21R\&D_Expenditure_intensity $(\mathrm{H} 2)$

+ C31Profit_intensity (H3)

+ C41New_product_intensity (H4)

+ C51Cooperative_projects (H5)

+ C61Granted_Patent (H6)

+ C71aattitude_of_involvement (H7a)

+ C71bEducation_level(H7b)

+ C71cManagement_experience(H7c)

+ Random Errorl

Innovation-stage: dependent variable of Innovation stage

C10Country: dummy variable, which has two values, 1 for China and 0 for France.

C1laAge (H1a): variable of firm age, which corresponds to H1a

C11bSize (H1b): variable of firm size, which corresponds to $\mathrm{H} 1 \mathrm{~b}$

C21R\&D_Expenditure_intensity (H2): variable of R\&D expenditure intensity, which corresponds to $\mathrm{H} 2$

C31bProfit_intensity (H3): variable of profit intensity, which corresponds to $\mathrm{H} 3$

C41New_product_intensity (H4):variable of number of cooperative innovation projects, which corresponds to $\mathrm{H} 4$

C51Cooperative_projects (H5):variable of cooperative projects, which corresponds to $\mathrm{H} 5$

C6Granted_patent (H6):variable of granted patents, which corresponds to H6 C71aattitude_of_involvement (H7a): variable of attitude of entrepreneur, which corresponds to $\mathrm{H} 7 \mathrm{a}$

C71bEducation_level(H7b): variable of Education level, which corresponds to $\mathrm{H} 7 \mathrm{~b}$

C71cManagement_experience(H7c): variable of Managerial Experience, which corresponds to H7c ) 
Table 5. Linear correlation results

\begin{tabular}{|c|c|c|c|c|c|}
\hline \multirow{2}{*}{ Model } & \multicolumn{2}{|c|}{ Non standardized rates } & standardized rates & \multirow{2}{*}{$\mathrm{t}$} & \multirow{2}{*}{ Sig. } \\
\cline { 2 - 4 } & $\mathrm{A}$ & Standard deviation & Bêta & & \\
\hline (Constant) & 1.953 & .406 & & 4.813 & .000 \\
\hline COUNTRY & -.810 & .135 & -.420 & -6.015 & .000 \\
\hline EDUCATION LEVEL & -.008 & .049 & -.009 & -.172 & .863 \\
\hline MANAGEMENT YEARS & .013 & .007 & .115 & 1.958 & .052 \\
\hline FIRM AGE (LN) & -.117 & .092 & -.088 & -1.271 & .206 \\
\hline FIRM SIZE (LN) & .225 & .060 & .288 & 3.774 & .000 \\
\hline R\&D EXPENDITURE INTENSITY (LN) & .115 & .058 & .104 & 1.983 & .049 \\
\hline PROFIT INTENSITY & .117 & .041 & .149 & 2.866 & .005 \\
\hline ATTITUDE INNOVATION & .171 & .064 & .156 & 2.656 & .009 \\
\hline COOPERATIVE PROJECT & .040 & .023 & .128 & 1.789 & .076 \\
\hline NEW PRODUCT INTENSITY & 1.203 & .384 & .212 & 3.135 & .002 \\
\hline GRANTED PATENTS INTENSITY & .015 & .007 & .120 & 2.076 & .040 \\
\hline \multicolumn{2}{|c|}{ a. Variable dependant : INNOVATION STAGE } & & \\
\hline
\end{tabular}

\section{Discussion}

This section discusses data analysis and the implications of regression results. H1a: The hi-tech SME's age is positively correlated with the innovation stage of hi-tech SME.

- H1b: The hi-tech SME's size is positively correlated with the innovation stage of hi-tech SME.

Generally speaking, researchers argue that both the hi-tech SME's age and its size are positively correlated with the innovation stage. Yet, prior studies (Leonard-Barton [3]; Sorensen \& Stuart [4] ${ }^{110}$ have argued that SME's age is negatively correlated with innovation performance. Moreover, the literature reports contradictory findings on the influence of SME's age and innovation capabilities. According to Mairesse et al. [1], and Wang et al. [2] ${ }^{92}$, etc., the size of the company contributed positively to an SME's innovation performance. Nevertheless, Leonard-Barton [3] and Sorensen \& Stuart $[4]^{93}$ find that the firms' age has a negative effect on its ability to learn new competencies and thus to innovate.

In this research, the SME's age is not correlated with the innovation stage, which implies that, on one hand, the hi-tech SME's innovation stage is not sig-

\footnotetext{
91 Leonard-Barton, D., (1997); Sorensen, J.B., Stuart, T.E., (2000): op. cit.

92 Mairesse, J., et al., (2005) : Wang, Y., Ellinger, A. D., (2009) : op. cit.

93 Leonard-Barton, D., (1997): Sorensen, J.B., Stuart, T.E., (2000): op. cit.
} 
nificantly increased with the age of the firm; on the other hand, larger hi-tech SMEs are likely to have more resources to innovate than smaller firms. However, older hi-tech SME firms do not have significantly more innovative capabilities than the younger firms.

- H2: The R\&D expenditure intensity is positively correlated with the innovation stage.

In line with the literature, it comes as no surprise that hi-tech SME's R\&D expenditure intensity is positively correlated with the innovation stage. The hypothesis is definitely supported by the results of the data analysis.

- H3: The profit intensity is positively correlated with the innovation stage.

With regard to 'profit intensity', the result of the linear regression demonstrates that more innovative firms produce more profits per employee than less innovative firms.

- H4: New product intensity is positively correlated with the innovation stage.

The linear regression model is formulated to examine the relationship between new product intensity and innovation stage. The analysis indicates that new product intensity has a significant impact on the firm's innovation stage, which means that the results support the $\mathrm{H} 4$ hypothesis. The significant correlation between new products intensity and innovation stage could be interpreted as meaning that new product enhances SME's innovation capability by increasing the firm's leverage through increased profits.

- H5: The number of co-operative innovation projects is positively correlated with the innovation stage.

Literature demonstrates that smaller firms tend to rely more on collaboration due to their limited resources, and the firm's size influences the available resources, strategy and performances. According to the resource-based theory, hi-tech SMEs are mostly likely to seek inter-firms resources to enhance their innovation capabilities. Data analysis confirms this theory and shows that the number of co-operative innovation projects is positively correlated with the innovation stage. Therefore, hypothesis H5 is supported.

- H6: The innovation stage is positively correlated with the number of granted patents.

Not surprisingly, higher levels of granted patents as innovation output is reported in more innovative firms which see themselves to be in a more technologically dominant situation. In this paper, hypothesis H6 is supported, which means that highly innovative hi-tech SMEs have a higher propensity to patent than medium and low innovative SMEs. 
- H7a: The importance of involvement in innovation activities is positively correlated with innovation capabilities.

- H7b: The education level of the entrepreneur is positively correlated with innovation capability.

- H7c: The Managerial Experience of the entrepreneur is positively correlated with innovation capability.

In this research, the education level of the entrepreneur does not show any significant impact on a firm's innovation capability. Although the education level in French firms appears to be slightly higher than that in Chinese firms, the data analysis demonstrates that the education level has no significant correlation with the innovation stage in the regression analysis. This study suggests that the education level of the entrepreneur is not significantly correlated with innovation capabilities and therefore hypothesis H7b is not supported. The attitude of involvement in innovation activities and managerial experience is reported to be positively correlated with innovation capabilities. The hypotheses $\mathrm{H} 7 \mathrm{a}$ and $\mathrm{H} 7 \mathrm{~b}$ are both supported by the data analysis.

- H8: The difference of innovation capabilities between China and France is statistically significant.

According to the results of the regression analysis, the individual variable 'country' is significantly correlated with the innovation stage. However, the value of individual variable 'country' is negative, which implies that the difference in innovation capabilities between China and France are significant, because the value of "country China" equals 1 and the value of "country France" is 0 . While the negative value is approached to the France country advantage, thus the result is obviously clarified. Therefore, the hypothesis $\mathrm{H} 8$ is shown to be statistically supported in this paper.

\section{Conclusions}

This research is the first comprehensive empirical study on the difference of hi-tech SMEs in China and France. Focusing on firm-level factors, it investigates a sample of hi-tech SMEs in two regions: Shanghai in China and Rhône-Alpes in France aiming at investigating any differences in innovation capabilities in the two countries.

\subsection{Key Results}

1. The importance of innovation capability for SMEs is definitely recognized by both France and China. According to the linear correlation analysis, the differences in innovation capability between hi-tech SMEs in China and hi-tech 
SMEs in France are significant, which means French hi-tech SMEs have more advantages to innovate than the Chinese ones.

2. The linear regression analysis of the firm characteristics (firm age and firm size) and innovation stages fills the gap in the literature, particularly with respect to the firms age which is not significantly correlated with the innovation stages.

3. Nevertheless, the firm size is a significant factor in determining whether to use an innovative strategy in hi-tech SMEs. Prior studies have found that the firm size has a significant impact on the innovation capabilities in various industrial sectors. This study confirms this finding in the hi-tech SME sector.

4. With regard to the level of education of entrepreneur, the independent variable 'education level' shows insignificant impact on hi-tech SMEs' innovation stage, suggesting 'education level' is not a significant hindrance to the SMEs innovation capabilities.

5. The innovation stage is positively correlated with 'granted patent intensity', revealing that the innovation stage enhances a SME's capabilities in acquiring technology patents.

6. The attitude towards involvement in innovation activities and managerial experiences is positively correlated with the innovation stage, which shows that the influence of the entrepreneur plays a vital role in innovation activities in hi-tech SMEs.

7. This research confirms that SMEs enter into more innovative stages owing to resources such as $\mathrm{R} \& \mathrm{D}$ expenditure, profit intensity and new product development and that cooperation is one of the key factors for hi-tech SMEs, because the number of inter-firm cooperation projects is positively correlated with innovation stage.

\subsection{Contribution to Knowledge}

The literature proposed a set of variables in examining the propensity of firms to innovate, ranging from firm resource variables, such as firm age, firm size, R\&D intensity, profit intensity and top manager characteristics, to output variables, such as granted patents, new products, etc. This research is focused on innovation capability variables, which consist of country, profit intensity, firm age, firm size, $\mathrm{R} \& \mathrm{D}$ expenditure intensity, new product intensity, number of cooperative innovation projects, granted patent, attitude of involvement in innovation activities, education level, managerial experience and develops a set of factual factors and a perceptive assessment system to measure the difference between the two countries based on innovation capabilities. Prior studies have evaluated innovation capabilities using various measurements, such as innovative input ( $\& \mathrm{D}$ personnel density and $R \& D$ expenditure, etc.), innovative output (the number of patents, the number of significant innovations, new product intensity, etc.). 
This research broadens the understanding of the relationship among the factors of innovation capabilities with an empirical research. All of these variables except that firm age and education level are correlated with innovation stage using linear correlation analysis, especially the variable of country which is negatively correlated with innovation stage. This result reveals that there is a significant difference of innovation capabilities between China and France.

The reason that profit intensity and firm size are positively correlated with innovation stage can be interpreted from the resourced-based theory (Eisenhardt and Schoonhoven [26]; Acs and Audretsch [46]; Chanaron et al.; [42]; Miotti\&Sachwald, 27] ${ }^{94}$ and Malerba et al. [75]; Andrew et al. [76]; Muller et al. [77]; Cordero [78]; ${ }^{95}$ ) whereby firms which have resources could get more resources to innovate.

The empirical study confirms that making use of external resources and taking advantage of business networks is a strategic option for firms operating in competitive and fast changing hi-tech industries.

\subsection{Contribution to Managerial Practice}

All the factors are combined to explain the importance of innovation capabilities. Each of these factors is indispensable for improving the innovation capabilities but any one of them on its own is not sufficient to push the firm to the next innovation stage. It means that the managers intending to engage in innovation should use several resources simultaneously rather than emphasizing one particular factor.

For example, the manager might consider R\&D intensity as the most important key factor to improve the innovation stage of the firm. However, this study demonstrates that other factors, such as inter-firm cooperative activities, could also fortify and improve its innovation capabilities. Due to a lack of in-house resources, inter-firm cooperation strategy is seen to be a shortcut for hi-tech SMEs to catch up with more innovative and larger enterprises. Sharing costs and $\mathrm{R} \& \mathrm{D}$ resources could make steam-line the innovative activities.

Managers of SMEs should not only focus on the firm's performance, but also the other innovative output factors.

94 Eisenhardt, K. M., Schoonhoven, C. B., (1996): Acs, Z.J., Audretsch, D.B., (1991): Chanaron, J.J., Birchall, D., Soderquist, K. (1996): Miotti\&Sachwald., (2003): op. cit.

95 Malerba, F., Orsenigo, L., (1993): Technological regimes and firm behavior, Industrial \& Corporate Change, Oxford, 2, 1: 45-72; Andrew, J.P., et al., (2007): Measuring Innovation 2007, A BCG Senior Management Survey, The Boston Consulting Group; Muller, A., Valikangas, L., Merlyn, P., (2005): Cordero, R., (1990): The measurement of innovation performance in the firm: an overview, Research Policy, 19: 185-192. 


\subsection{Limitations.}

1. This study conducted a survey in hi-tech industry in only one region in each country, Shanghai and Rhône-Alpes. Thus, the extent to which the results of this study could be generalized remains to be further investigated. Moreover, the generality of the findings in this study is limited due to the sampling frame and the survey regions. Sample firms come from Shanghai and Rhône-Alpes, which is a small percentage of the total provinces in China and in France, and the innovation activities in both of regions are above the average of each country.

2. Despite a careful selection of industries, data declared in questionnaire cannot be verified in official documents. Therefore, the homogeneity in industrial sectors might not be very high.

3. The low response rate is problematic reflecting a non-response bias. However, literature presents that Internet surveys usually have a low response rate because few correspondents in SMEs are likely to reply to the Internet questionnaire. It could be a common problem for collecting data via Internet in quantitative research.

4. Since there are some missing values in the data, results might be biased afterthe exclusion from the linear regression analysis.

5. There are probably other factors missed in this study, which could also bias the results of the linear correlation analysis.

\subsection{Further Research}

1. Limitations recognized about validity and representativeness indicate that additional research would be needed to examine whether the results found are valid for other regions in China and France as well as in other countries and regions.

2. Further research should be carried out on other factors affecting innovation capabilities.

3. Another issue to be investigated is using a linear regression model so as to deduce what happens if the effect of one predictor depends on another predictor.

4. Further research should also try to focus on particular industry in order to raise the accuracy of data analysis and the reliability of conclusion.

5. Future research could also target the influence of social factors, such as governmental administration, legal system and regional clusters.

6. In addition, culture determinants of the difference in innovation capability could be added into future study, with respect to differences in national cultures. 


\section{Literature}

[1] Mairesse, J., et al., (2005): The Importance of R\&D and Innovation for Productivity: A Reexamination in Light of the French Innovation Survey, Annals of Economics and Statistics / Annalesd'Économie et de Statistique, No. 79/80, Contributions in memory of ZviGriliches , 487-527.

[2] Wang, Y., Ellinger, A. D., (2009): Examining the relationships between information acquisition, entrepreneurial opportunity recognition, and innovation performance through the development and validation of a new measure to assess information acquisition in the high technology sector in Taiwan, International Journal of Entrepreneurship and Innovation Management, 9(3): 313-334.

[3] Leonard-Barton, D., (1997): Wellsprings of Knowledge, Boston, MA, Harvard Business School Press.

[4] Sorensen, J.B., Stuart, T.E., (2000): Aging, Obsolescence, and Organizational Innovation, Administrative Science Quarterly, 45: 81-112.

[5] Natarajan, B., et al., (2008): Firm age and innovation, Industrial and Corporate Change, 17, 5: 1019-1047.

[6] Mlouka, S.B., Sahut, J.M., (2008): La taille est-elle un facteur déterminant de la compétitivité des entreprises, La Revue des Sciences de Gestion, 233, 5: 77-86.

[7] Cohen W.M., Klepper S., (1996): Firm size and the nature of innovation within industries: The case of process and product R\&D, Review of Economics and Statistics, 78: 232-243.

[8] Kim, J.Y., Lee, S.J., Marschke, G., (2009): Relation of firm size to R\&D productivity, International Journal of Business and Economics, 8: 7-19.

[9] Becker, J.P., et al., (2005): Innovation Effects of Science-Related Technological Opportunities: Theoretical Considerations and Empirical Findings for Firms in the German Manufacturing Industry, JahrbücherfürNationalökonomie und Statistik, 225. 2, 130-150.

[10] St-Pierre, J. et al., (2010) : L'effet de l'âge et de la taille sur la performance financière et économique des PME, Journal of Small Business \&Entrepreneurship, 23, $2: 287-306$.

[11] Hall, B. H., Ziedonis. R. H., (2001): The patent paradox revisited: An empirical study of patenting in the U.S. semiconductor industry, 1979-1995, RAND Journal of Economics, 32(1): 101-128.

[12] Merges, R.P., (1997): Patent Law and Policy. Charlottesville, VA: Michie.

[13] Lee, Seong-Sang; Kim, Yeonbae. (2010): The impact of efficiency parameters on firms innovative activities: Evidence from Korean firm-level data, Innovation Management Policy \& Practice, 12, 3: 283-297.

[14] Kortum, S., Lerner J., (2000): Assessing the contribution of venture capital to innovation, RAND Journal of Economics, 31: 674-692. 
[15] Vermeulen, P.A.M., O’shaughnessy, K.C., De Jong, J.P.J., (2003): Innovation in SMEs: An empirical investigation of the input-throughput-output-performance model, EIM Business \& Policy Research, Zoetermeer, The Netherlands.

[16] Garcia-Vega, M., (2006): Does technological diversification promote innovation? An empirical analysis for European firms, Research Policy, 35: 230246.

[17] Beneito, P., (2006): The innovative performance of in-house and contracted R\&D in terms of patents and utility models, Research Policy, 35: 502-517.

[18] Han, Y.J., Lee, W.Y., (2007): The effects of the characteristics of Korean firms on the patent production function, Economics of Innovation and New Technology, 16: 293-301.

[19] Brouwer, E., Kleinknecht, A. (1999): Innovative output and a firm's propensity to patent: An exploration of CIS micro data, Research Policy, 28: 615624.

[20] Cohen, W.M., Nelson, R.R., Walsh, J.P., (1998): Appropriability conditions and why firms patent and why they do not in the American manufacturing sector, Unpublished Working Paper, Carnegie Mellon University, Pittsburgh.

[21] Arundel, A., Kabla, I., (1998): What percentage of innovations are patented? Empirical estimates for European firms, Research Policy, 27: 127-141.

[22] Scherer, F. M., (1999): New Perspectives on Economic Growth and Technological Innovation, Brookings, Washington. P188.

[23] Mansfield, E., (1986): Patents and innovation: An empirical study, Management Science, 32: 173-181.

[24] Berger Consultants, (1994): The use of patent protection in Europe: A representative survey committed by the European Patent Office, EPOscript, München.

[25] Chabchoub N., Niosi J. (2005): Explaining the propensity to patent computer software, Technovation, 25: 971-978.

[26] Eisenhardt, K. M., Schoonhoven, C. B., (1996): Resource Based View of Strategic Alliance Formation: Strategic and Social Effects in Entrepreneurial Firms, Organization Science 7(2): 136-150.

[27] Miotti, L., Sachwald, F., (2003): Cooperative R\&D: Why and with Whom? An Integrated Framework of Analysis, Research Policy, 32: 1481-1499.

[28] Doz, Y., Hamel, G., (1998): Alliance Advantage: The Art of Creating Value through Partnering, Boston, MA: Harvard Business School Press.

[29] Mowery, D, Oxley, J, Silverman, B., (1998): Technological overlap and interfirm cooperation: implications for the resource-based view of the firm, Research Policy, 27: 507-523.

[30] Hagedoorn, J., Schakenraad, J., (1994): The effect of strategic technology alliances on company performance, Strategic Management Journal, 15:291309. 
[31] Gulati, R., (1993): The dynamics of alliance formation, doctoral dissertation, Harvard University, Cambridge, MA.

[32] Dickson, P. H., Weaver, K.M., (1997): Environmental Determinants and Individual-Level Moderators of Alliance Use, Academy of Management Journal, 40, 2: 404-425.

[33] Shrader, R. C., (2001): Collaboration and performance in foreign markets: The case of young high-technology manufacturing firms, Academy of Management Journal, 44 (3): 45-60.

[34] Zongling Xu, et al. (2008): Networking and innovation in SMEs: evidence from Guangdong Province, China, Journal of Small Business and Enterprise Development, 15, 4: 788-801.

[35] Ritter, T., Gemünden, H.G., (2003): Network competence: its impact on innovation success and its antecedents, Journal of Business Research, 56: 745-55.

[36] Rothwell, R., (1991): External Networking and Innovation in Small and Medium-sized Manufacturing Firms in Europe, Technovation, 11, 2: 93-112.

[37] Cohen, W.M., D. Levinthal. (1989): Innovation and Learning: The Two Faces of R\&D, Economic Journal, 99: 569-596.

[38] Bougrain, F., Haudeville, B., (2002): Innovation, Collaboration and SMEs Internal Research Capacities, Research Policy, 31:735-747.

[39] Freeman, C., (1991): Networks of innovators: A synthesis, Research Policy, 20: 499-514.

[40] Miller, D., (1983): The correlates of entrepreneurship in three types of firms, Management Science, 29, 7: 770-791.

[41] Yuan-Duen, L., (2006): Leadership style and innovation ability: An empirical study of Taiwanese wire and cable companies, Journal of American Academy of Business, 9(2): 218-222.

[42] Chanaron, J.J., Birchall, D., Soderquist, K. (1996): Managing Innovation in SMEs, A Comparison of Companies in the UK, France and Portugal, International Journal of Technology Management, 12, 3: 291-305.

[43] Rada, J.F., (1987): The Management of Technology, EFMD Colloquium on Technical Change, Geneva.

[44] Morin, J., (1985) : L'excellence technologique, Publi-Union, Éditions J. Picollec.

[45] OECD and the Chinese Ministry of Science and Technology, (2007): OECD Reviews of Innovation Policy China Synthesis Report, Paris.

[46] Acs, Z.J., Audretsch, D.B., (1991): R\&D, firm size, and innovative activity, in Acs, Z.J., Audretsch, D.B., (Eds), Innovation and Technological Change: An international Comparison, Harvester Wheatsheaf, New York, NY.

[47] Zhang Yuming, et al. (2011): Study on the Evaluation and Prediction of ISME's Growth-based on data of Listed Companies in the Growth Enterprise Market, Journal of Shandong University, 5: 32-38 (in Chinese). 
[48] Zhang Haiyan (2008): Empirical Study on Performance Appraisal and R\&D Expenditure of hi-tech SMEs in China, Doctoral Thesis, Capital University of Economic and Business, Beijing.

[49] Bradley, S.W., et al., (2012): Capital Is Not Enough: Innovation in Developing Economies, Journal of Management Studies, 49, 4: 684-717.

[50] Kim, S., Huang, K. H., (2011): Winning strategies for innovation and hightechnology products management, Journal of Business Research, 64(11): 1147-1150.

[51] Waterman N., Kirk M., (1992): The Innovation Management Tool Kit, in Bowen A., Ricketts M. Stimulating in Industry, The Challenge for the United Kingdom, NEDO, London.

[52] Kim Linsu, (1997): Imitation to Innovation, Harvard Business School Press, Boston.

[53] Okimoto, D., Saxonhouse, G., (1987): Technology and the Future of the Economy, in Yamamura, K., Yasuba, Y., Eds, (1987): The Political Economy of Japan, 385-419, Stanford, Stanford University Press.

[54] Leonard-Barton, D., (1992): Core Capabilities and Core Rigidities: A Paradox in Managing New Product Development, Strategic Management Journal, 13: 111-125.

[55] Chanaron, J.J., Metcalfe, J. S., (1990) : L'économie schumpétérienne, Technologies, Idéologies et Pratiques, IX, 1: 73-91.

[56] Acs, Z. J., Audretsch, D. B., (1988): Innovation in Large and Small Firms: An Empirical Investigation, American Economic Review, 78, 678-690.

[57] Narin, F., Noma, E., Perry, R., (1987): Patents as factors of corporate technological strength, Research Policy, 16: 143-155.

[58] Trompenaars, F., (1994): Riding the Waves of Culture: Understanding Diversity in Global Business, Irwin Professional Publishing, Burr Ridge, IL.

[59] Fukuyama, F., (1995): Trust: The Social Virtues and the Creation of Prosperity, The Free Press, New York, NY.

[60] Nisbett, R.E., (2003): The geography of thought: How Asians and Westerners think differently and why, New York: Free Press.

[61] Mueller, S., Thomas, A., (2001): Culture and entrepreneurial potential: a nine country study of locus of control and innovativeness, Journal of Business Venturing, 16, 1: 51-75.

[62] Van Everdingen, Y.M., Waarts, E., (2003): The effect of national culture on the adoption of innovations, Marketing Letters, 14, 3: 217-232.

[63] Hofstede, G. et al., (2005): Cultures and Organizations: Software of the Mind, 2nd Edition, McGraw-Hill USA, 2005.

[64] Chen Xinfang and Pan Xinlu, (2010): Research on Innovation and International Competitive Capability, China National Natural Science Foundation of China (NSFC)'s Program (Project No.: 70573096), China Science Press, Beijing. 
[65] Zhao, W., Arvanitis R., (2008): The Unequal Development of China: Innovation Capabilities and the Co-existence of Different Industry Growth Patterns, Région et Développement, 28: 61-85.

[66] China National Bureau of Statistics, (2009): China Statistics Yearbook on hi-tech technology industry, Beijing.

[67] INSEE, (2012) : Les PME de Rhône-Alpes innovent pour se développer, Analysis Report $\mathrm{N}^{\circ} 180$, novembre.

[68] Chanaron, J.J., Scaringella, L., (2016): Grenoble-GIANT Territorial Innovation Models: Are investments in research infrastructures worthwhile?,Technological Forecasting \& Social Change, 112: 92-101.

[69] European Commission, (2009): Commission Staff Working Document on the implementation of Commission Recommendation of 6 May 2003 concerning the definition of micro, small and medium-sized enterprises, Brussels.

[70] Zikmund, W.G., (1991): Exploring Marketing Research, International edition, Dryden Press, Orlando, FL.

[71] Bryman, A. (2004): Social research methods (2nd ed.), Melbourne: Oxford University Press.

[72] Field A., (2009): Discovering Statistics using IBM SPSS Statistics, SAGE.

[73] Myers, R. H., (1990): Classical and Modern Regression with Applications, PWS-Kent Publishing Company.

[74] Tabachnick, B.G., Fidell, L.S., (1996): Using Multivariate Statistics, 3rd, New York, HarperCollins.

[75] Malerba, F., Orsenigo, L., (1993): Technological regimes and firm behavior, Industrial \& Corporate Change, Oxford, 2, 1: 45-72.

[76] Andrew, J.P., et al., (2007): Measuring Innovation 2007, A BCG Senior Management Survey, The Boston Consulting Group.

[77] Muller, A., Valikangas, L., Merlyn, P., (2005): Metrics for innovation: guidelines for developing a customized suite of innovation metrics, Strategy \& Leadership, 33(1): 37-45.

[78] Cordero, R., (1990): The measurement of innovation performance in the firm: an overview, Research Policy, 19: 185-192. 


\author{
Rui Luo \\ Institut za poslovnu administraciju Univerzitet Grenoble Alpes, Francuska \\ JEAN-JaQues ChanaRoN \\ Grenoble Ecole de Management, Francuska
}

\title{
INOVACIJSKE MOGUĆNOSTI VISOKE TEHNOLOGIJE MALIH I SREDNJIH PREDUZEĆA (MSP): Komparativna analiza Kine i Francuske
}

Cilj ovog istraživanja je da obogati naučna saznanja pružajući novi uvid u aktuelne inovativne aktivnosti visokotehnoloških MSP. Osim toga, istraživanje se usredsređuje na empirijsku proveru pitanja i hipoteza koje potiču od vizionarskih ideja drugih naučnika kao što su Šumpeter, Friman, Šanaron i drugi. Ova studija istražuje i upoređuje visoko tehnološka mala i srednja preduzeća u Kini i Francuskoj ukazujući na razlike u inovacionim sposobnostima između ove dve zemlje. Empirijsko istraživanje je zasnovano na sveobuhvatnom upitniku. U okviru uzorka preduzeća su nasumično izabrana iz Šangaja u Kini i Ronsko-alpske oblasti u Francuskoj. Da bi se kontrolisala egzogena industrijska varijansa, uzorak je obuhvatio firme iz dve zemlje sa istim procentom industrijskih sektora. Oslanjajući se na kvantitativnu analizu, studija zaključuje da su razlike u sposobnostima inoviranja značajne. Štaviše, faze inoviranja visokotehnoloških kompanija zavise od nekih ključnih faktora, kao što su izdaci za istraživanje i razvoj, veličina kompanije, odobreni patenti, intenzitet profita, novi proizvodi i slično, u pozitivnoj su korelaciji sa inovacionim sposobnostima. Rezultati ukazuju da, u poređenju sa većim kompanijama, visokotehnološka MSP imaju specifične mogućnosti za inovacije koje su određene njihovim ograničenjima resursa $i$ određenom inovacijskom strategijom.

Ključne reči: inovacije, sposobnost, mala i srednja preduzeća (MSP), performance, Francuska, Kina 